\title{
Simulators of mammary pathologies enclosed on a breast phantom for image quality control in mammography
}

Simuladores de patologias mamárias posicionados em um phantom de mama para controle de qualidade da imagem em mamografia

\author{
I. F. Souza ${ }^{1}$; L. B. Nogueira ${ }^{2}$; T. P. R. Campos ${ }^{3}$ \\ ${ }^{1}$ Hospital das Clínicas, Federal University of Minas Gerais, 30130-100, Belo Horizonte, Minas Gerais, \\ Brazil \\ ${ }^{2}$ Anatomy and Imaging Department, Federal University of Minas Gerais, 30130-100, Belo Horizonte, \\ Minas Gerais, Brazil \\ ${ }^{3}$ Nuclear Engineering Department, Federal University of Minas Gerais, 31270901, Belo Horizonte, Minas \\ Gerais, Brazil
}

lucibn19@yahoo.com.br

(Recebido em 03 de setembro de 2015; aceito em 09 de dezembro de 2015)

This paper addresses the development of simulator of breast pathologies for image quality control in mammography. Simulators of neo density's objects had been used for reproducing the breast pathologies. These objects had been adhered between two dental wax plates, inserted in an anthropomorphic and anthropometric compressed breast (AACB) phantom and submitted to radiological expositions. The AACB phantom is constituted of glandular, adipose and skin equivalent tissues, representing a fibro adipose breast with $50 \%$ of glandular and $50 \%$ adipose tissues. Radiographies of the AACB breast phantom were taken in the conventional and computerized systems. Two standard commercial breast phantoms referenced by the Brazilian College of Radiology and by the American College of Radiology were used as validation. After the expositions, qualitative image evaluation were carried through, identifying how many objects of the pathologies had been depicted, following the norms of quality control demanded by the Brazilian control agencies. The quality control measurements related to the pathology's identifications, comparing with the standard breast phantoms, provided similar values. The simulating objects of mammary pathologies enclosed on the AACB phantom provide a suitable system for image quality control in mammography.

Keywords: breast phantom, mammary pathologies, image quality control

Este trabalho relata o desenvolvimento de dispositivos simuladores de patologias mamárias, para controle de qualidade da imagem em mamografia. Para o desenvolvimento dos dispositivos foram utilizados materiais simuladores indicativos de neodensidade. Esses materiais foram aderidos entre duas placas de cera odontológica, inseridos em um phantom de mama comprimida antropomórfico e antropométrico e submetidos a exposições radiológicas. Este phantom de mama é constituído por tecidos equivalentes (TE): TE glandular, TE adiposo e TE pele, que representa uma mama fibroadiposa com 50\% de tecido glandular e $50 \%$ de tecido adiposo. O phantom de mama comprimida foi radiografado nos sistemas convencional e computadorizado. Dois phantoms de mama comerciais referenciados pelo Colégio Brasileiro de Radiologia e Colégio Americano de Radiologia foram usados para validação. Após as exposições foram realizadas avaliações qualitativas das imagens, sendo possível determinar quantas estruturas patológicas foram visibilizadas, seguindo orientações das normas de controle de qualidade exigidos pelos órgãos brasileiros de fiscalização. O phantom de mama antropomórfico e antropométrico alcançou resultados similares nos testes de qualidade, comparado com o simulador de mama comercializado no mercado. Os dispositivos simulares de patologias mamárias podem ser factíveis de serem utilizados para testes de qualidade da imagem em serviços de mamografia.

Palavras-chaves: phantom de mama, patologias mamárias, controle da qualidade da imagem 


\section{INTRODUCTION}

The International Commission on Radiation Units and Measurements (ICRU) recommends the use of a set of objects that can reproduce similar radiological response of biological tissues, as tissue substitutes [1]. In the radio diagnostic centers, equivalent tissues or phantoms are used as simulator, defined by the ICRU 48 and International Commission on Radiological Protection (ICRP) 26 as structures that contain one or more equivalent tissues [2, 3]. That is any material that simulates a body and its properties of radio attenuation, which depends mainly on the chemical composition of the objects and the energy spectra applied in the radiological equipment's [2].

Among the diverse applications of phantoms, including the various areas of image diagnosis, the image quality control in mammography has been distinguished as a noble application [4]. The equivalent tissue simulators used for this end generally mimic a compressed breast with four and five centimeters thickness, with knowing shape and geometric size, enclosing some objects that produce similar radiological images to the normal anatomic structures and abnormal sites often present in the woman breast, as micro calcifications, staple fibers, tumor masses and nodules of low contrast. The quality of the image in mammography shall be evaluated using the radiographic breast simulator similar to a human breast as described by the Brazilian College of Radiology $[5,6]$.

The Ordinance-453 [7], defined as O-453/MS, of the Secretariat of Sanitary Monitoring and the Ministry of Health $(\mathrm{MH})$, Brazil, regulates the directives of radiological protection in medical and dental radiodiagnoses. Its $\S 4.19$ establishes that all mammography system shall be tested with a phantom for accomplishment of the quality control measurements. And, the $\S 4.48$ recommends an image quality control evaluation monthly, based on a breast equivalent phantom adopted for mammography endorsed by the American College of Radiology. Mammography shall not be carried through if the minimum criterion of image quality control cannot be reached [7].

The O-453/MS recommends the phantom of the American College of Radiology (ACR) to be used in the mammographic services. It has approximately $4.2 \mathrm{~cm}$ of thickness and represents a breast composition of $50 \%$ of glandular and $50 \%$ adipose tissues ${ }^{(7,8)}$. It contains the following details: staple fibers with diameters of $1.56 ; 1.12 ; 0.89 ; 0.75 ; 0.54$ and $0.40 \mathrm{~mm}$; micro calcifications with diameters of $0.54 ; 0.40 ; 0.32 ; 0.24$ and $0.16 \mathrm{~mm}$ and tumor masses with thicknesses and diameters of $2.0 ; 1.0 ; 0.75 ; 0.50$ and $0.25 \mathrm{~mm}$. The method to evaluate the quality of image in the ACR breast phantom consists of counting the object number depicted in each experimental group of objects. According to the tests recommended by O-453/MS, the mammographic system must be capable to at least identify in the image four staple fibers, three groups of tumor masses and of micro calcifications [7, 8].

In Brazil, the CDM breast phantom (Center of Mammary Diagnosis) complies of all the requirements established by the O-453/MS for image quality control and those often used for processes of evaluation of image quality, in mammographic services ${ }^{(9,10)}$. This phantom simulates a compressed breast with four and five centimeters thickness and uses acrylic plates with dimensions of $48 \times 120 \times 160 \mathrm{~mm}$, contends a plate of wax, $10 \times 7 \times 140 \mathrm{~mm}$, in which structures are inserted. These objects shall simulate: tumor masses (five spherical plates of nylon with diameter and thicknesses of $9.5 / 3.4 \mathrm{~mm} ; 7.7 / 2.9 \mathrm{~mm} ; 5.5 / 2.0 \mathrm{~mm} ; 4.0 / 2.0 \mathrm{~mm}$ and $2.0 / 0.8 \mathrm{~mm}$, respectively); micro calcifications (five sets of aluminum oxide with diameters of $0.45 ; 0.35 ; 0.30 ; 0.25$ and $0.18 \mathrm{~mm}$ ); staple fibers (six linear objects of low contrast of $1.0 \mathrm{~cm}$ of length and diameters of $0.40 ; 0.60 ; 0.70 ; 0.80 ; 1.2$ and $1.4 \mathrm{~mm}$ ) and neodensities (disks of low contrast with diameters of $6.0 \mathrm{~mm}$ and thicknesses of $0.1 ; 0.2 ; 0.3 ; 0.4 ; 0.5 ; 0.6 ; 0.7$ and 0.8 $\mathrm{mm}$ ) [9-11]. The method to evaluate the image quality of the CDM phantom also consists of counting the object number depicted in each group. In accordance with the norms of the National Institute of the Cancer, for the tumor masses, from the five spherical plates of nylon at least up to the fourth plate must depicted; for micro calcifications (detail of high contrast), up to the fourth set of micro calcifications it must be depicted at least; for staple fibers (linear details of low contrast) from the six provided staple fibers at least up to the fourth must be depicted. 
For discs of low contrast, from the eight discs that simulate neo densities, seven discs must be depicted on the image [12].

The AACB phantom consists of three equivalent tissues (TEs): glandular, adipose, and skin TEs. Adipose TE was manipulated in the same volumetric ratio to glandular one, being the adipose TE molded involving by the glandular TE. The ratio of 50:50 was chosen to represent a fibro adipose breast corresponding of women with age between 30 to 50 years that present average radiographic density. This object represents a breast in craniocaudal projection in position adjusted for mammographic examination. The final dimensions presented by phantom of developed compressed breast are of $4.5 \mathrm{~cm}$ of thickness, $15.0 \mathrm{~cm}$ of length and $6.0 \mathrm{~cm}$ of height [13-15].

The main goal of this paper is to present the AACB phantom and its application in image quality control. The objects which simulate breast pathologies will be addressed and described. Image quality measurements will be performed in three institutions, intercompared with commercial breast phantoms, taken the limit of reference addressed on the O-453/MS.

\section{MATERIALS AND METHODS}

\subsection{The development of the pathology's simulators for the AACB phantom}

Table 1 presents the objects and its dimensions used on the development of pathology's simulator. It had been elaborated with similar shape described on the patent MU 8200268-1U Breast Radiographic Simulator [11].

Table 1 -Objects used for developing the pathology's simulators

\begin{tabular}{|c|c|c|}
\hline Quantity & Objects (pathology) & Dimensions \\
\hline 4 & dental wax plates $n^{\circ} .7$ & $\begin{array}{l}\text { length of } 9.0 \mathrm{~cm} \text {, width of } 3.0 \mathrm{~cm} \text {, height of } 0.2 \\
\mathrm{~cm} .\end{array}$ \\
\hline 5 & $\begin{array}{l}\text { spherical plates of nylon (tumor } \\
\text { mass) }\end{array}$ & $\begin{array}{c}\text { diameters and thickness of } 9.5 \mathrm{~mm} \times 3.4 \mathrm{~mm} ; 7.7 \\
\mathrm{~mm} \times 2.9 \mathrm{~mm} ; 5.5 \mathrm{~mm} \times 2.0 \mathrm{~mm} ; 4.0 \mathrm{~mm} \times 2.0 \\
\mathrm{~mm} \text { e } 2.0 \mathrm{~mm} \times 0.8 \mathrm{~mm} .\end{array}$ \\
\hline 4 & $\begin{array}{l}\text { set of five elements based on grain of } \\
\text { aluminum oxide (micro calcification) }\end{array}$ & $\begin{array}{l}\text { diameters of } 0.45 \mathrm{~mm} ; 0.36 \mathrm{~mm} ; 0.24 \mathrm{~mm} \text { and } \\
0.16 \mathrm{~mm} .\end{array}$ \\
\hline 8 & polyester discs (nodule) & $\begin{array}{l}\text { diameters of } 6.0 \mathrm{~mm} \text {; thickness of } 0.1 \mathrm{~mm} ; 0.2 \\
\mathrm{~mm} ; 0.3 \mathrm{~mm} ; 0.4 \mathrm{~mm} ; 0.5 \mathrm{~mm} ; 0.6 \mathrm{~mm} ; 0.7 \mathrm{~mm} \\
\text { and } 0.8 \mathrm{~mm} .\end{array}$ \\
\hline 6 & wires of nylon (fibers) & $\begin{array}{l}\text { length of } 10 \mathrm{~mm} \text {; diameters of } 0.4 \mathrm{~mm} ; 0.6 \mathrm{~mm} \text {; } \\
0.7 \mathrm{~mm} ; 0.8 \mathrm{~mm} ; 1.2 \mathrm{~mm} \text { and } 1.4 \mathrm{~mm} \text {. }\end{array}$ \\
\hline
\end{tabular}

The wax plate accommodates in its interior five spherical plates of nylon, four groups of grains of aluminum oxide, eight polyester discs and six wires of nylon. Spherical plates of nylon had been used to simulate tumor masses of diverse sizes. The grains of aluminum oxide had been used to simulate malignant micro calcifications associated to the neoplastic breast tissues. The polyester discs had simulated the injuries or lesions of low contrast referent to the nodules of low contrast (measuring the limit of viewing circular objects of low contrast). The wires of nylon had simulated long fibers of tissue that reproduce the neoplastic tissue whose imaging is possible in a breast mammography.

Two sets of wax plates had been prepared, with the following distributions on the pathology's simulator:

- Group 1 - organized by a row of grains of aluminum oxide and a row of polyester disc, as shown in Figure 1A

- Group 2 - organized by a row of spherical plates of nylon and a row of wires of nylon, as shown Figure 1B. 


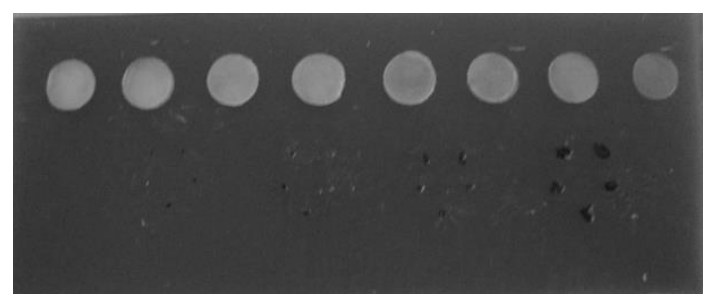

A

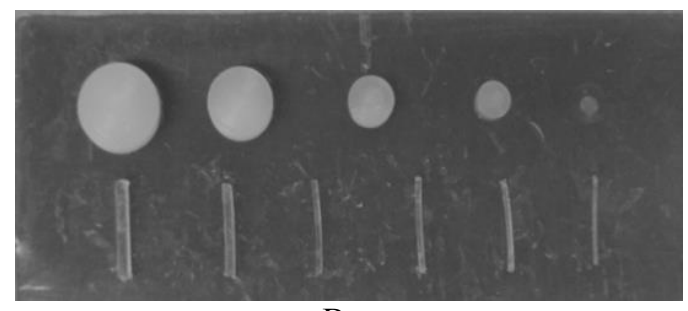

B

Figure 1: (a) Group $1-1^{a}$ row of polyester discs and $2^{a}$ row of grains of aluminum oxide; and, (b) Group $2-1^{a}$ row of spherical plates of nylon and $2^{a}$ row of wires of nylon.

In order to have the objects adhered in the wax plates, a spatula and a metallic clamp were used for such procedure. The closing of the wax plates was carried through with a warm metallic spatula, in which it allowed to join the laterals of the plates, preventing the adhered objects to move from its initial positioning.

The expositions of the objects were carried through for accomplishing qualitative evaluations of the quality of the images. The two plates with groups 1 and 2 of pathology's simulators had been placed into the AACB phantom, between glandular and adipose TEs and skin TE.

\subsection{Expositions of the AACB phantom}

The expositions of AACB phantom had been carried through in mammographic center of three distinct institutions, codified as $\mathrm{A} 1, \mathrm{~B} 1$ and $\mathrm{C} 1$. The $\mathrm{A} 1$ institution possess conventional mammographic system; the B1 and the $\mathrm{C} 1$ use computerized mammographic system (CR). In the three institutions, one exposition was performed with a standard breast phantom assumed on the service of to quality control, and two expositions with the AACB phantom assembling with the pathology's simulator in its interior. The three mammographic equipment's had been adjusted in the following conditions: semiautomatic control of exposition, kilovoltage of $28 \mathrm{kV}$, non-application of control of optic density (position " 0 ") and breast phantom placed at craniocaudal incidence (CC), as shown in the Figure 2A. The following mammographic system was applied on the A1 institution: a mammography- MAMMOMAT 1000 with molybdenum target and filter (Mo-Mo), film processor Kodak and screen-film combination MINR 2000 Screen. On the $\mathrm{C} 1$ institution, the system was a mammography-Siemens 3000 New Mammomat with molybdenum target and filter (Mo-Mo), Scanner Kodak Direct View 850, image plateKodak Direct View EHR M2 Screen. And, on the B1 institution, it was used a mammographyGE Senographe DMR with molybdenum target and rhodium filter and film processor Agfa CR MM 3.0 Mammo.

A professional of the radiological sector of each institution followed the execution of the expositions. Each plate of pathology's simulator was positioned into the breast phantom before compression and the compression was performed until presenting ideal for the measurements. The mammographic centers of $\mathrm{A} 1$ and $\mathrm{C} 1$ institutions had used as reference the CDM breast phantom approved by the Brazilian College of Radiology, Figure 2B, and the B1 institution used the ACR breast phantom as reference from the American College of Radiology. 


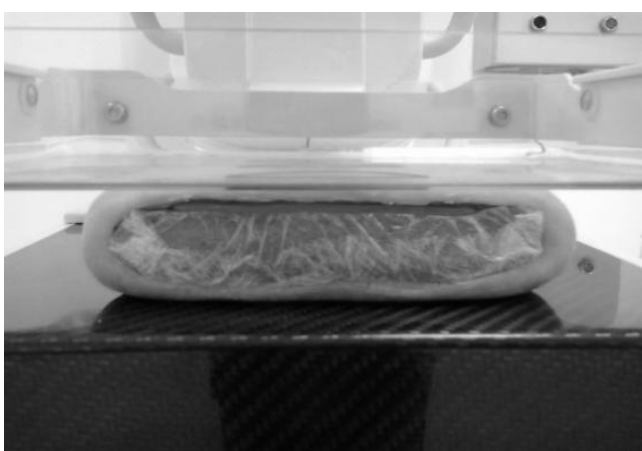

A

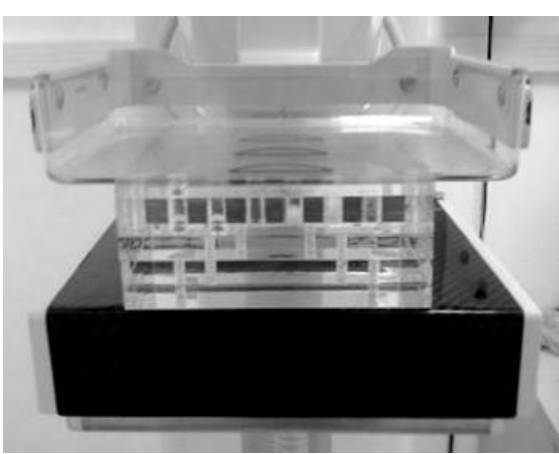

$\mathrm{B}$

Figure 2: (a) AACB phantom with pathology's simulator, in the CC position and (b) the CDM breast phantom.

\subsection{Analyses of the image quality of the pathology's simulator}

For analyzing the images, an exposition of the AACB phantom without the pathology's simulator was carried through to take as image pattern. Later, the expositions with AACB phantom with the pathology's simulator and the standard phantoms were taken for evaluating the image quality control. The images had been qualitatively analyzed in a negatoscopic of mammography's centers.

\section{RESULTS AND DISCUSSION}

\subsection{Expositions of the AACB phantom}

Figure 3 shows the mammographic image of the AACB phantom without the pathology's simulator. The presence of non-homogeneous texture is observed in the image representing the glandular TE. This texture was associated to the components of the glandular TE, in the process of development of gelatinous synthetic tissue.

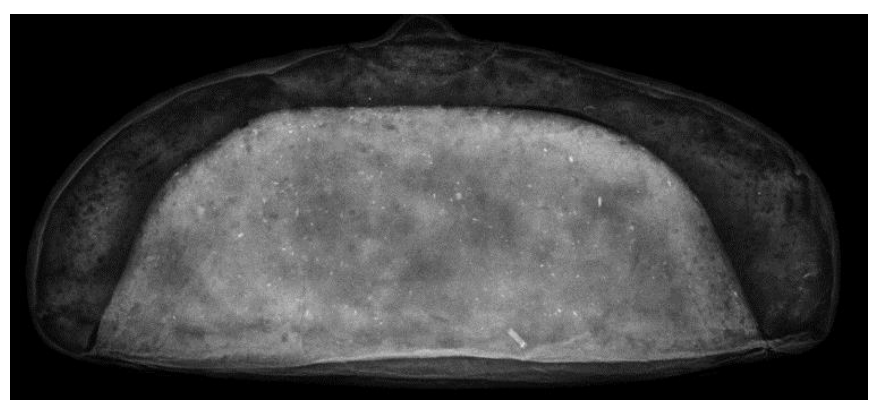

Figure 3: Mammographic image of the AACB phantom.

\subsection{Image quality measurements of the AACB phantom at HA institution.}

Table 2 shows the pathologies depicted in the measurements of image quality on the CDM and AACB phantoms from the HAC institution. All objects were identified in the CDM phantom, in accordance with the boundary-values recommended by O-453/MS. For the AACB phantom, four pathology's simulator have been depicted well. However, the seventh nodule of low contrast was not identified, in accordance with the boundary-values adopted by the standard agencies. This fact is justified by the texture of glandular TE that is not as homogeneous as it is in the commercial standard phantom. Thus, the real difficulty in analyzing pathology on the breast has been reproduced on the image of the AACB phantom, mainly in dense breasts; while 
in the CDM phantom the image is presented in higher contrast which drives to easily identification of the pathology's simulators.

Table 2 - The image quality measurements applied to the CDM phantom and to the AACB phantom at A1

\begin{tabular}{cccc}
\hline Pathologies & $\begin{array}{c}\text { Reference (identified) } \\
\text { CDM phantom }\end{array}$ & $\begin{array}{c}\text { Reference (identified) } \\
\text { A A CB phantom }\end{array}$ & $\begin{array}{c}\text { Limit value } \\
\text { CDM phantom }\end{array}$ \\
\hline Nodule & $8(7)$ & $8(6)$ & 7 \\
\hline $\begin{array}{c}\text { Micro } \\
\text { calcification }\end{array}$ & $5(4)$ & $4(4)$ & 4 \\
\hline Fibers & $6(6)$ & $6(4)$ & 4 \\
\hline Tumor Mass & $5(4)$ & $5(4)$ & 4 \\
\hline
\end{tabular}

\subsection{Image quality measurements of the AACB phantom at CD institution.}

Table 3 shows the pathologies identified in the measurements of image quality on the CDM and the AACB phantoms at the CD institution. All objects were identified in the CDM phantom, in accordance with the boundary-values recommended by O-453/MS. For the AACB phantom, four pathology's simulator have been depicted well. The seventh nodule of low contrast was not identified. On the CD institution, a computerized mammographic system was used. It is possible that the imaging of fibers has been improved by the larger contrast present on digital image while the HA institution has applied a conventional mammographic system.

Table 3 - The image quality measurements applied to the CDM phantom and to the AACB phantom at C1

\begin{tabular}{cccc}
\hline Pathologies & $\begin{array}{c}\text { Reference (Identified) } \\
\text { CDM Phantom }\end{array}$ & $\begin{array}{c}\text { institution. } \\
\text { Reference (Identified) } \\
\text { AACB Phantom }\end{array}$ & $\begin{array}{c}\text { Limit Value } \\
\text { CDM Phantom }\end{array}$ \\
\hline Nodule & $8(7)$ & $8(6)$ & 7 \\
\hline $\begin{array}{c}\text { Micro } \\
\text { calcification }\end{array}$ & $5(4)$ & $4(4)$ & 4 \\
\hline Fibers & $6(5)$ & $6(5)$ & 4 \\
\hline Tumor Mass & $5(4)$ & $5(4)$ & 4 \\
\hline
\end{tabular}

\subsection{Image quality measurements of the AACB phantom at $\mathrm{HC}$ institution.}

Table 4 shows the number of pathologies identified on the ACR and AACB breast phantoms used at the HC institution. The data demonstrated that ACR phantom reached the boundaryvalues of the number of identification of the pathologic structures adopted to evaluate the image quality measurements. However, it is important to comment that this simulator does not possess objects representative of nodules. Also, it is constituted by a lesser amount of representative objects relative to micro calcifications and tumor masses. Thus, it is demanded that a lesser boundary-value for ACR breast phantom is identified; different from the CDM breast phantom that demands higher numbers of identification.

Table 4 - The image quality measurements applied to the ACR phantom and to the AACB phantom at BI

\begin{tabular}{cccc}
\hline Pathologies & $\begin{array}{c}\text { Reference } \\
\text { (Identified) } \\
\text { ACR Phantom }\end{array}$ & $\begin{array}{c}\text { institution. } \\
\text { (Identified) } \\
\text { AACB Phantom }\end{array}$ & $\begin{array}{c}\text { Limit Value } \\
\text { ACR Phantom }\end{array}$ \\
\hline Nodule & - & $8(6)$ & - \\
\hline $\begin{array}{c}\text { Micro } \\
\text { calcification }\end{array}$ & $5(4)$ & $4(4)$ & 3 \\
\hline Fibers & $6(4)$ & $6(5)$ & 4 \\
\hline Tumor Mass & $5(4)$ & $5(4)$ & 3 \\
\hline
\end{tabular}


A computerized mammographic system was used to expose the AACB phantom. The following objects had not been identified: a fiber, a nodules of low contrast and a mass. These results are similar to the reference values from ACR and CDM phantom, based on the simulator objects of pathologies enclosed into AACB phantom. Therefore, for the two measurements carried through with the AACB phantom, the results had been equivalents.

In relation to the validation of the mammographic services, it is important to note that the three institutions were register on the online Atalanta System, maintained by MS, which means that all three were submitted to a mensal inspection. Therefore, the standard pattern of image quality of the mammographic services has been demonstrated by the Atalanta System besides, the findings here agree with the conformity of the three services of mammography [16].

\section{CONCLUSION}

As conclusion, the anthropomorphous and anthropometric compressed breast phantom, called AACB phantom, can be used for measurements of image quality in mammography. It is justified by the level of register found in imaging of the simulator objects referent to the pathologies, similar to the requirements requested by the current legislation. Herein, the methods of assembling tools for simulating breast pathologies was well described to be used in the image quality control in mammography. Such procedures can be followed by other institutions to improve the mammography's diagnosis.

\section{ACKNOWLEDGMENTS}

The authors are thankful to the Radiology Center, Hospital das Clínicas, Federal University of Minas Gerais, the Radiology Center, Hospital Alberto Cavalcanti- FHEMIG and the Centro de Desenvolvimento da Tecnologia Nuclear (CDTN), Belo Horizonte, MG, Brazil.

\section{REFERENCES}

1. ICRU 44. Tissue substitutes in radiation dosimetry and measurements. International Commission on Radiation Units and Measurements. Report 44. Bethesda: MD, 1989.

2. ICRU 48. Phantoms and computational models in therapy diagnosis and protection. International Commission on Radiation Units and Measurements. Report 48. Bethesda: MD, 1992.

3. ICRP. Recommendations of the International Commission on Radiological Protection. ICRP Publication 26. Ann. ICRP 1 (3), 1977.

4. Pina DR, Morceli J, Duarte SB, Netto TG. Optimization of mammographic images. Radiol Bras. 2006; 39(5):351-354, doi:10.1590/S0100-39842006000500010.

5. Correa RS, Peixoto JE, Silver LD, Dias CM, Nogueira MS, Hwang SF, et al. Impact of a program of diagnostic imaging quality control in mammography centers of the Federal District, Brazil. Radiol Bras. 2008; 41(2):109-114, doi:10.1590/S0100-39842008000200010.

6. Mascena EN. Computational analysis of radiographic images of the breast phantom. [Master's Dissertation], CCEN. João Pessoa (PB): Federal University of Paraíba at João Pessoa, 2010.

7. Ordinance-453. Guidelines for radiological protection in medical and dental radiology. Secretariat of Sanitary Monitoring and Ministry of Health. Brazil, 1998.

8. Hendrick RE, Bassett L, Botsco MA, et al. Mammography quality control manual. Reston, Va: American College of Radiology, 1999.

9. Correa RS, Freitas- Junior R, Peixoto JE, Rodrigues DCN, Lemos MEF, Dias C M, et al. Effectiveness of a quality control program in mammography for the Brazilian National Health System. Rev Saúde Pública. 2012; 46:769-776.

10. Oliveira, MGN. Evaluation and characterization of the scattering of X-rays in tissue and mammographic simulators using Monte Carlo simulation. [Master's Dissertation], DEN/UFRJ. Rio de Janeiro (RJ): Federal University of Rio de Janeiro, 2005. 
11. Peixoto JE inventor. Radiographic simulator of the breast. Brazil patent MU 8200268-1 U. 2003; Sep 23.

12. Brazil. Mammography practice to control. Ministry of Health, National Cancer Institute. Rio Janeiro: Brazil, 2007.

13. Campos TPR, Thompson L, Nogueira LB, Duarte IL, Dias AD, Silva CHT, et al, inventors. Simulators objects anthropomorphic and Anthropometric, tissues and organs of the human body. Brazil patent BR PI 0141004465-5 A2. 2012; May 8.

14. Nogueira LB, Campos TPR. Radiological response of ceramics and polymeric devices for breast brachytherapy. Int J Appl Radiat Isot. 2012; 70:663-669, doi:10.1016/j.apradiso.2012.01.006.

15. Nogueira LB, Silva HLL, Campos TPR. Experimental dosimetry in conformal breast teletherapy compared with the planning system. Int J Appl Radiat Isot. 2015; 97:93-100; doi:10.1016/j.apradiso.2014.12.022.

16. Atalanta. [http://atalanta.cdtn.br]. Quality Control of Mammography Examinations Held in Institutions, Clinics, Hospitals and Laboratories of Belo Horizonte and Minas Gerais [updated 2014 Oct 15]. 